\title{
Engineering Women Faculty in institutes provides an inspiration to working women: a case study
}

\author{
Dr. J. S. Awati ${ }^{1}$, Dr. S. B. Awati ${ }^{2}$, Dr. S. A. Patil ${ }^{2}$, Dr. M. R. Patil ${ }^{2}$ \\ ${ }^{1}$ Ass. Prof., R.I.T, Sakharale, Maharashtra. \\ ${ }^{2}$ System Operator, D.K.T.E's Engineering and textile institute, Ichalkaranji, Maharashtra \\ ${ }^{3}$ Head of ETC Department, D.K.T.E's Engineering and textile institute, Ichalkaranji, Maharashtra \\ ${ }^{4}$ Principal, Jain AGM Institute of Technology, Jamkhandi, Karnataka. \\ 1 jayashree.awati@gmail.com \\ 2sbawati@gmail.com \\ ${ }^{3}$ shrinivaspatil@gmail.com \\ ${ }^{4}$ Minakshirpatil@gmail.com
}

\begin{abstract}
Engineering women playing multiple roles in engineering institutes. Engineering women perform their role as a teacher very effectively. Engineering women handle administrative work assigned them systematically. Engineering women look carefully towards their family. Engineering women balance their career and family life. This paper provides an inspiration to working women for balancing their career and family. This paper supports for stress management.
\end{abstract}

Keywords: Engineering, women, stress, family, career, management.

\section{Introduction:}

Faulty in engineering institutes are talented, well qualified (as per AICTE and UGC rules). Engineering faculties are men as well as ladies. The qualification for the faculty positions both for ladies and men are same. Ladies in Assistant Professor Position are M.E. or M. Tech. The ladies faculties at the position of Associate Position are $\mathrm{PhD}$. Some of the ladies faculties are handling higher positions in institutes such as director, dean and head of department.

Academic performance index for ladies faculty and men faculty are same for annual increments. Ladies faculties in institutes are carry out the lectures, tutorials, seminars, projects and practical assigned to them as per AICTE or UGC norms. Sometimes they carry out the excess load as per UGC norms. Ladies faculties are involved in teaching learning, question paper setting, syllabus setting, evaluation and invigilation. Ladies faculties in institutes are involved in professional related activities of students, co-curricular and extra co-curricular activities of students. Ladies faculties in institutes are members of ISTE, IETE, IET, BMISE, AIENG, ISTD, etc. Ladies faculties organize the workshops, seminars and conferences at National as well as International. They worked the research projects with students. They handle the sponsor projects and consultancy projects if available. Ladies faculties present their papers in National and International conferences at national and international level. Ladies faculties write books and publish papers in journals. Every year ladies faculties undergo training programs. Ladies faculties are involved in soft skill development of students.

\section{Objectives:}

- Motivate the working women

- Presenting the leadership qualities required for working women

- Motivating work life balance to working women

\section{Methodology:}

Methodology followed is direct interview method. The data is collected through primary as well as secondary method. The variables involved are faculty position and education. Indirect variable are qualification, Academic Performance
${ }^{1}$ Ass. Prof., R.I.T, Sakharale, Maharashtra
${ }^{1}$ jayashree.awati@gmail.com 
Index and family responsibility, additional responsibility and fulfilments. Survey is based on the following hypothesis:

- Ladies faculties in institutes balance their work life.

- Ladies faculties upgrade their skills, qualifications and knowledge.

The survey is done in Shivaji University affiliated institutes established more than 12 years ago.

\section{Scope of the projects:}

Inspire the girls to pursue their career in engineering. Perspiration the girls to become as an engineer field are good, challenging, dedicated and exciting work life. The women leave engineering workplace faster than men engineers due to following reasons:

i. Work life balance: balancing career, family and health.

ii. Workplace unfriendly and aggressive.

iii. Leaving the workplace is changing the work environment for ladies engineers

iv. Strict time followed by industry.

v. Women engineers leave the jobs due to lack of confidence or not properly finding the mentors.

vi. Women engineers choose to go away without argumentative rising fight for their perfection and further development.

This paper is the one step to guide women engineers to balance their work, family and health. Inspire the working women to progress with healthy environment. This paper motivates the working women to stay stable, progress and achieve their goals. This paper will help the organization to reduce their retention ratio.

5. Engineering Women Faculty in institutes: Engineering ladies faculties believe themselves. They have very good self confidence. Ladies faculties understood the keys to success. Ladies faculties have positive attitude. They motivate the students with positive attitude. They do not feel bad with others progress, money and position. They know very well their weakness and strengths. Always they are trying to overcome their weaknesses. They consult with seiners and believe to ask the solutions to problems faced by them. They accept very quickly the surrounding environment and mix up quickly in the surrounds. +They believe to work. They don't think that they are perfect. They work with their whole capacity. Ladies faculties are the capacity builders. Girl students as well as boys always prefer to talk their problems with ladies faculties in their institutes. Engineering women faculties are very good counsellor.

6. Qualities having Women engineering faculties:

Engineering ladies faculties have the following qualities:

i. Leadership: Leadership is the very important skill of human. For ladies faculties this skill comes by nature. E.g. women are leader in their family. Some of the leadership qualities are explained below:

$>$ Best Performance: Good leader performs best in their career. This is the first quality of ladies faulty. They follow rules and regulations. They work hard and believe to win. Women engineer faculty performs well in the institutes as well as in their homes. Ladies faculties increase their knowledge. They run as the technology runs. They attend workshops and industrial training programs to enhance of their knowledge and skills.

$>$ Democratic Behavior: This is the one more leadership quality. All engineering ladies faculties have this quality. They guide the students without criticizing them. They motivate the students systematically with positive attitude and trust the students. They work with students.

$>$ Vision: Ladies faculties in colleges set their long term as well as short term goals. Ladies faculties follow the institutes vision and mission. They know very well that what to do and what not to follow. They are the supporter in institutes as well in their homes.

$>$ Risk acceptor: They know the global challenges. They are familiar with technology changes. They took risk to operate with new technology. They take risks to develop applications.

$>$ Good planning: Engineering ladies faculties are good planners. They follow time. They are the perfect time manager. They understood that if time passes, it will not retain again.

ii.Best Counselor: Ladies facilities suggest the students how best to go ahead and avoid conflicts. Guide and give advice to students.

iii.Good Listener: Listen from students as well as rest of the peoples.

iv.Lifelong Learner: Ladies Engineering faculties are lifelong learners. They are perusing higher studies as well upgrading their knowledge.

v.Team Player: Good team player in institute as well as in their home.

vi.Creator: Ladies teachers are good creators. They are busy to create new things.

vii.Good Communicator: They are good communicator to students, institute and in homes.

A. Work life Balance:

Engineering ladies faculties balance their career as well as their family life. Engineering ladies faculties plays the following rolls: 1 . Teacher, 2. Wife, 3.Mother, 4. Daughter, 5. Sister, 6. Friend, 7. Daughter in law, 8. Aunt, 9. Cousin. 10. Niece, etc. Ladies faculties fulfil all the rolls responsibility with their hard work. Engineering ladies faculties in institutes have developed the skills in such a way that they can change the rolls very quickly. E.g. when engineering ladies faculties are in institutes they work as teachers, this is their role as a teacher. When engineering ladies faculties reached their home they turn their role as a mother, sister, daughter -in-law, etc. Engineering ladies faculties perform different roles simultaneously. They also perform the rolls of friends, neighbours and good citizen of India. Engineering ladies faculties' retention ratio is very less. By handling the students they become trained. Ladies faculties are the motivators to other working women. Engineering ladies faculties adjust trolls as per position, place and situation.

Engineering ladies faculties not took their burdens and tension in their homes. Because ladies faculties not get time to take tension and they don't to disturb their family members. Another region is that they know that if they take 
tension, the burden of the work goes increasing. So they leave the tension and work happily. They maintain their family happy. They balance their work and career. They try to live happy in institute as well as in home. Engineering ladies faculties are very good stress manager. They are the good time manager. They are house manager when they are in home. They schedule their timetable systematically.

B. Results: The survey was done by total 214 ladies faculties' in engineering institutes.

1. Ladies faculties upgrade their skills, qualifications and knowledge: The results below shows the qualifications of ladies faculties:

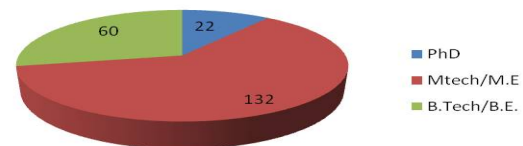

Fig. 1 Qualifications of ladies faculties

Conclusion: Engineering women playing multiple roles. Engineering women perform their role as a teacher very effectively. Engineering women balance their work, career and family life. They are the inspiration to working women for balancing their career and family. They are lifelong learners. Some of the skills having engineering ladies faculties are helpful for working women. Engineering ladies faculties are good leader, counsellor and good listener.
2. Ladies faculties in institutes balance their work life: The results below show the family relation with

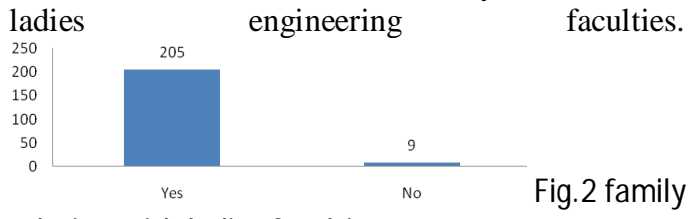
relation with ladies faculties

3. API score of women engineering faculties in one selected engineering institute is given below.

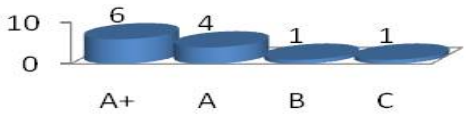

Fig. 3 API score of ladies faculties in a institute 